\title{
壁がある地面近傍でホバリングするヘリコプタロータの数值解析*1 Numerical Analysis of Helicopter Rotor Hovering in Close Proximity to the Ground with a Wall
}

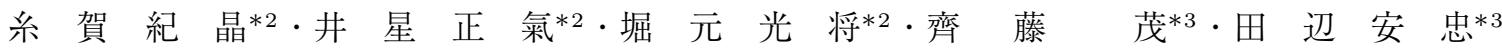 \\ Noriaki Itoga, Naohiro Iboshi, Mitsumasa Horimoto, Shigeru Saito and Yasutada Tanabe
}

Key Words : Helicopter Rotor, Ground Effect, Recirculation, CFD

\begin{abstract}
In rescue operations and emergency medical services, helicopters are frequently required to operate near the ground with obstacles such as buildings and sidewalls of highway. In this paper, numerical analysis of helicopter rotor hovering in close proximity to the ground with an obstacle is done by solving unsteady 3D compressible Euler equations with an overlapped grid system. The obstacle is simulated by a wall vertically set up on the ground. The parameters for numerical analysis are the rotor height and distance from the rotor-hub-center to the wall. The effects of combinations of these parameters on the flowfields around the rotor, inflow distributions on the rotor disc and behaviors of blade flapping motion are discussed. It is also clarified the cause that the helicopter rotor hovering in close proximity to the ground with a wall does not have the enough ground effect depending on the combinations of these parameters.
\end{abstract}

\section{1. は じめ に}

ホバリングや垂直離着陸等の優れた飛行性能を有するへ リコプタは, 現在では人員や物資の輸送に限らず, 消火や ドクターヘリに代表されるような救命救急活動, あるいは 大規模災害時における広域的な防災・人命救助等において も非常に重要な役割を担うようになっている。このような 運用において, ヘリコプタは建物や高速道路の側壁等, 空 間を制限する物体がある地面近傍を飛行することが想定さ れる，こうした飛行環境では，ロータ後流は空間的制限を 及ぼす物体の影響により複雑に変形しうるため, 推力ゃト ルク等のロータの空力性能は, 平地上のような一般的な地 面効果を受ける場合とは異なると推察される。

そのため，筆者らは，近年，空間を制限する物体を壁で 模擬した狭い空間上でホバリングする模型ロータに関する 実験的研究を行い, 壁がある場合には地面効果内にもかか わらずロータのトルク係数が増大することや，ブレードフ ラッピング運動がロータ高さ, 壁高さ, 壁間隔等の組み合 わせに依存した挙動を示す等の知見を得ている1 4).これ らの現象は, 壁に沿って上昇するロータ後流とロータとの 干涉により引き起こされていると考えられるが, 要因の詳 細については未だ十分に解明されていない.

そこで, 本研究では, 壁がない場合, 及び 1 枚の壁があ る地面近傍でホバリングするへリコプタロータに対し, 非

\footnotetext{
*1 (C) 2010 日本航空宇宙学会

平成 21 年 11 月 4 日, 第 47 回飛行機シンポジウムにおいて一部 発表. 平成 22 年 5 月 17 日原稿受付

*2 防衛大学校システム工学群航空宇宙工学科

*3 宇宙航空研究開発機構航空プログラムグループ
}

定常 3 次元圧縮性 Euler 方程式を基礎方程式とした重合格 子法による数值シミュレーションを行い, ロータ高さ, 壁 間隔の組み合わせがロータまわりの流れ場, ロータ面のイ ンフロー分布, ブレードのフラッピング運動の振幅や位相 角に与える影響を検討する。また，それらをもとに，ロー 夕高さと壁間隔の組み合わせによっては, 壁近傍でホバリ ングするロータが十分な地面効果を得られない要因につい て明らかにする。

\section{2. ロータの作動環境}

ロー夕の作動環境を第 1 図に示す。ロー夕は建物や高速 道路の側壁等を模擬した壁がある地面近傍でホバリング飛 行している. ロータ高さ $h$ はロータ中心と地面間の距離で, 壁間隔 $w_{\mathrm{wr}}$ はロータ中心から壁までの距離で定義する。ま た, $h_{\mathrm{w}}$ は地面からの壁高さ， $l_{\mathrm{w}}$ は壁長さを表す。なお, $h$, $w_{\mathrm{wr}}, h_{\mathrm{w}}, l_{\mathrm{w}}$ はすべてロータ半径 $R$ で除した量を表すと する。

Cartesian 座標系はロータ中心を原点とし, 壁面と平行 に $x$ 軸, 壁面と垂直に $y$ 軸を, 鉛直上方が $z$ 軸正方向にな るように右手系で設定している。ブレードは上方から見て $z$ 軸まわりを反時計方向に翼端マッハ数 0.65 の翼端速度で 回転しており, ブレード方位角 $\psi$ は $x$ 軸正方向から測る. したがって，壁を設置した位置は $\psi=3 \pi / 2$ 側となる。ま た, 壁の水平方向の中心位置は, $z$ 軸から壁に下ろした垂 線の足と一致している。ロータは, 翼型が NACA0015 で ある剛体 2 枚ブレードの関節型ロータで, ヒンジに弾性拘 束を与えていない. ロータ半径 $R$ で除した無次元量のヒン ジオフセット, ルートカットアウトはそれぞれ $0.02,0.2$ で ある.ブレードピッチ角はコレクティブピッチ角 $\theta_{0}=8^{\circ}$ 


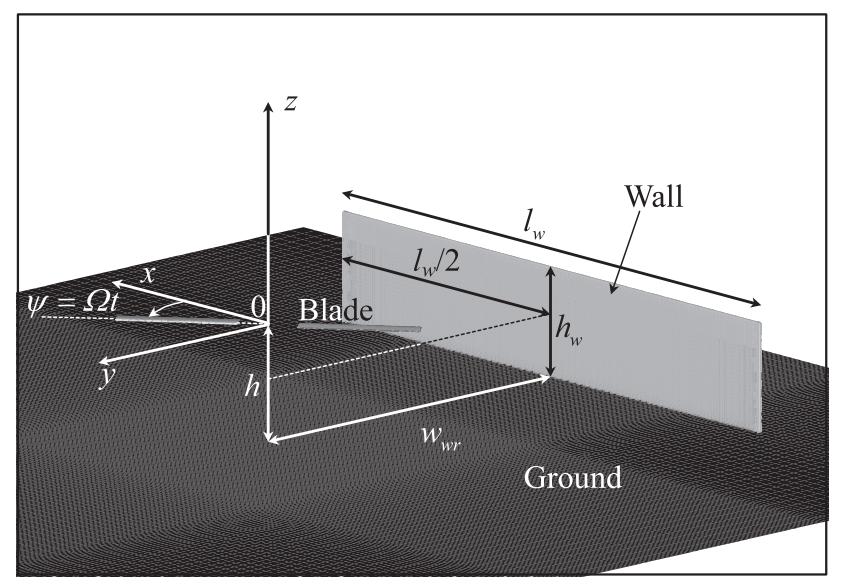

第 1 図 ロータの作動環境

（一定）とし，サイクリック入力は与えていない.

\section{3. 計 算 方 法}

3.1 基礎方程式と計算スキーム 基礎方程式は，時間 変数を含む一般曲線座標系で記述した非定常 3 次元圧縮性 Euler 方程式である。 また，ブレードのフラッピング運動 を解析するため, フラッピング運動方程式を基礎方程式と 同時に解いている。 この際, フラップモーメントは, CFD 解析で得られたブレード上の圧力分布から算出している.

基礎方程式の空間微分項の離散化は風上差分法により行 い，流束評価にはRoeの平均化による流束差分法5)を用い ている。 また，空間的に高次精度化するために山本ら6)の 4 次精度 compact MUSCL 法を, 解の数值振動を避け単調 性を維持するために流束制限関数として minmod limiter を用いている。一方, 時間積分は Jameson ら7)による 4 段 階 Runge-Kutta 法により陽的に行っている.

3.2 計算格子 計算格子の全体図を第 2 図に示す。計算 格子は, 重合格子系で, 境界条件により底面が地面を表す背 景格子, 背景格子内を移動するブレードを囲むブレード格 子, 及び地面境界と接するように配置した壁を囲む壁格子 で構成されている.ブレード格子と壁格子は重ならないよう に作成したので, 物理量の情報交換は, ブレード格子と背景 格子間, 壁格子と背景格子間でそれぞれ行われる. 背景格子 は計算精度の向上を図るためロータ及び壁周辺に格子を集 中させている不等間隔の直交格子である。 また，ブレード格 子は O-H 型, 壁格子は C-H 型のトポロジーを持つ構造格子 である. 各格子の格子点数は, 背景格子が $209 \times 209 \times 131$ $=5,722,211$ 点, ブレード格子が $71 \times 121 \times 15=128,865$ 点, 壁格子が $99 \times 170 \times 15=252,450$ 点の総数約 610 万 点であり, 計算空間の大きさは, 縦方向, 横方向に対しロー 夕半径の 8 倍, 高さ方向には 5 倍としている.

\section{4. 結果と考察}

第 1 表に計算条件を示す，ロータの作動環境としてロー 夕高さ $h$ と壁間隔 $w_{\mathrm{wr}}$ は, 過去の実験結果1 4) をもとに, ロータの空力性能やブレードフラッピング運動に対する壁

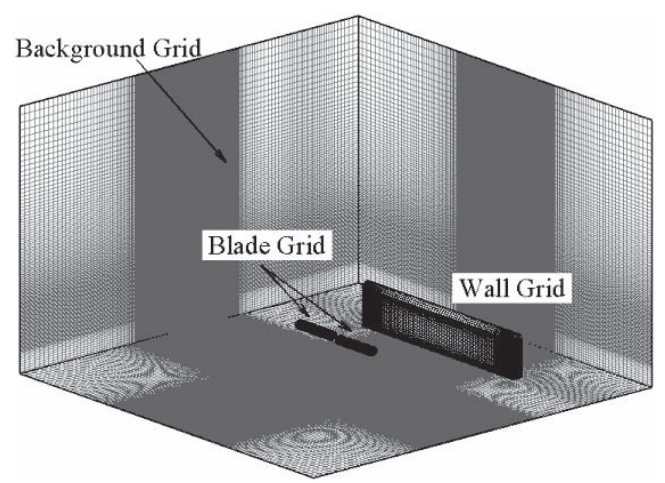

第 2 図計算格子

第 1 表 計算条件

\begin{tabular}{ll}
\hline ロータ高さ $h$ & $0.8,1.7$ \\
壁間隔 $w_{\mathrm{wr}}$ & $\infty, 1.25,1.5,2.5$ \\
壁高さ $h_{\mathrm{w}}$ & 0.75 \\
壁長さ $l_{\mathrm{w}}$ & 4 \\
\hline
\end{tabular}

の影響が特徵的であった $h=0.8,1.7$ と $w_{\mathrm{wr}}=\infty, 1.25$, $1.5,2.5$ の組み合わせとし, 壁高さ $h_{\mathrm{w}}$ と壁長さ $l_{\mathrm{w}}$ は一 定とした. $h_{\mathrm{w}}$ は $0.75, l_{\mathrm{w}}$ は計算空間の大きさから 4 とし たが，実験結果のロータの定常空気力に対する壁の影響は $l_{\mathrm{w}}=3 \sim 6.4$ の範囲において同様の特徴を示す8) ことを確 認している. 数值計算は, すべての計算条件において時間 刻み $\Delta \psi=6.23 \times 10^{-4}$ とし, 初期条件を静止流とする impulsive start で実施した，計算終了の判定には，ロータ 推力倸数 $C_{\mathrm{T}}$ とロータ面のインフロー分布の影響が表れる ブレードフラッピング運動の位相角 $\phi_{1}$ を用いた。本解析 では, ロー夕 5 回転の間の平均值に対して, $C_{\mathrm{T}}$ が $\pm 1 \%$, $\phi_{1}$ が $\pm 30^{\circ}$ の範囲内になったときに計算を終了した，収束 までに要したロー夕の回転数は, 少ないもので約 20 回転, 多いもので約 30 回転である. ただし， $h=1.7, w_{\mathrm{wr}}=1.5$ の場合は， $C_{\mathrm{T}}$ に対しては約 $\pm 1 \%$ 範囲で一定となった が, 他の場合と比べると位相角は著しく変動した，そのた め, ロー夕面下, 壁との間で循環流が形成されることや循 環流の大きさが一定しないこと等, ロータまわりの流れ場 に関する特徵の再現性を確認して 40 回転で計算を終了し ている.

4.1 ロータまわりの流れ場 ロータまわりの流れ場の 詳細を知ることは，ロータ空気力やブレードフラッピング 運動の挙動を理解するうえで非常に有用である. 本節では, ロー夕高さと壁間隔の組み合わせごとにロータまわりの流 れ場について説明する。第 3 図〜第 10 図は, 各計算条件 におけるロータまわりの流れ場をパーティクルトレイスと 速度ベクトルを用いて示したものである。 パーティクルト レイスは，ブレード方位角 $\psi=\pi$ から見た図で，パーティ クルは，基準となるブレードが 5 回転するごとにブレー ドの後縁から放出し, 放出位置により色を変えて示してい

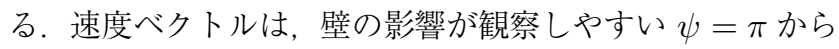
見た $y z$ 平面の速度べクトルであり, 2 格子間隔で示してい る。また，ロー夕後流境界の目安として瞬間流線を描いて 


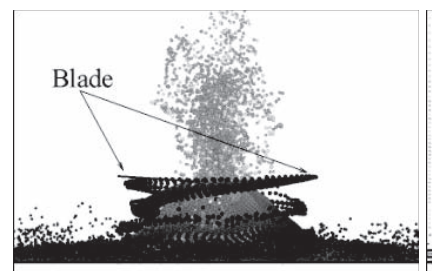

(a) パーティクルトレイス

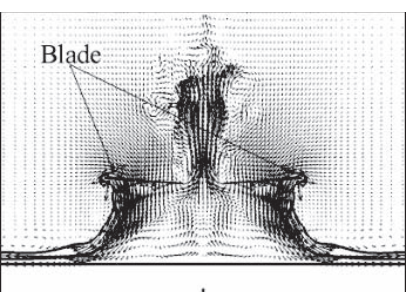

(b) $y z$ 平面速度ベクトル

第3図 ロー夕まわりの流れ場 $\left(h=0.8, w_{\mathrm{wr}}=\infty\right)$

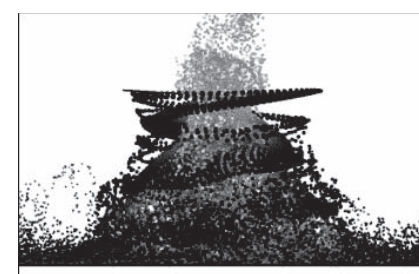

(a) パーテイクルトレイス

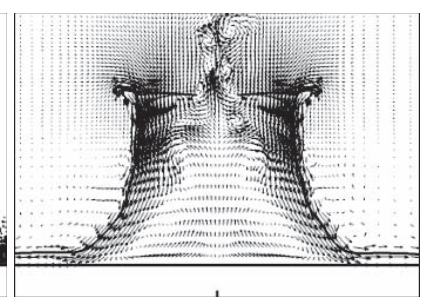

(b) $y z$ 平面速度ベクトル

第4図 ロータまわりの流れ場 $\left(h=1.7, w_{\mathrm{wr}}=\infty\right)$

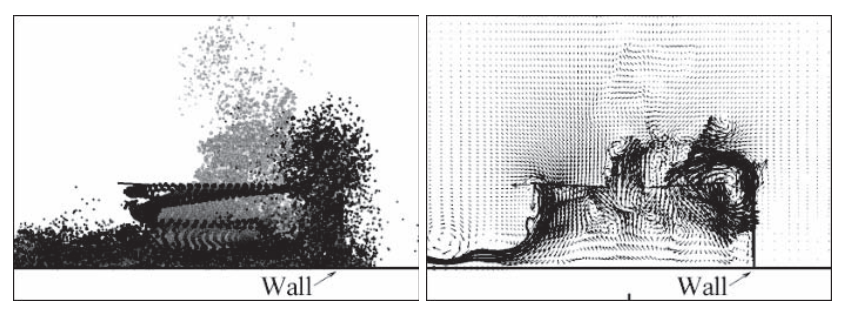

(a) パーティクルトレイス (b) $y z$ 平面速度ベクトル

第5 図 ロータまわりの流れ場 $\left(h=0.8, w_{\mathrm{wr}}=1.25\right)$

おり，図の下端にはロータ中心位置を印してある。

ロータ高さ $h=0.8$, 壁間隔 $w_{\mathrm{wr}}=\infty$ 及び $h=1.7$, $w_{\mathrm{wr}}=\infty$ の場合のロータまわりの流れ場を第 3 図, 第 4 図にそれぞれ示す、ロー夕後流は，いずれの場合もらせん 構造をしており, 概ね軸対称で地面に近づくにつれて外側 に拡がっている。 また，翼根部付近にはアップウォッシュが 発生しており， $h=0.8$ の方が地面効果が大きいため, よ り大きなアップウォッシュとなっている。 このように, 周 知の地面効果を受けるロー夕まわりの流れ場の様子9) がよ く表現されている.

ロー夕高さ $h=0.8$, 壁間隔 $w_{\mathrm{wr}}=1.25$ の場合のロー夕 まわりの流机場を第 5 図に示す, 壁側のロー夕後流は, 壁 の外側へほとんど流出することなく翼端部に再循環する流 れを形成しており，壁の影響が影著に表れている。この流 れは, 他の場合と比較すると, ブレードの回転開始後, ロー 夕後流境界が地面に到達することなく, 早い段階で形成さ れた。この再循環する流れの影響により, 翼根部のアップ ウォッシュは, $h=0.8, w_{\mathrm{wr}}=\infty$ の場合ほど高く上昇せ ず壁側に傾くことが示されている。 また，速度べクトルを $h=0.8, w_{\mathrm{wr}}=\infty$ の場合と比較すると, 壁側のロー夕後 流境界形状や後流境界内部の速度べクトルの様子が異なっ ており，ロー夕後流構造の対称性が大きく失われているこ

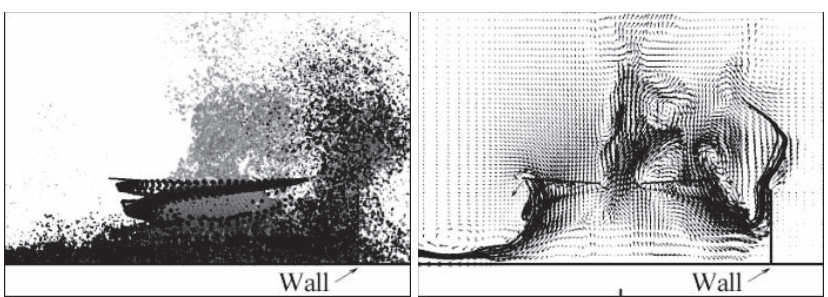

(a) パーティクルトレイス

(b) $y z$ 平面速度べクトル

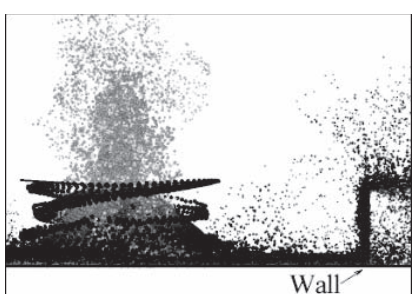

(a) パーティクルトレイス

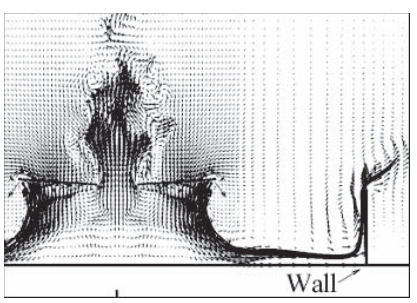

(b) $y z$ 平面速度ベクトル

第 7 図 ロータまわりの流れ場 $\left(h=0.8, \quad w_{\mathrm{wr}}=2.5\right)$

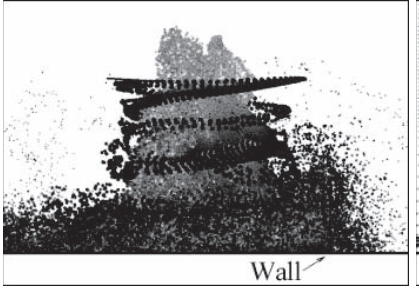

(a) パーティクルトレイス

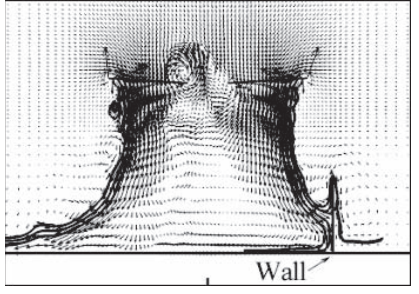

(b) $y z$ 平面速度べクトル

第8図 ロー夕まわりの流れ場 $\left(h=1.7, w_{\mathrm{wr}}=1.25\right)$

とがわかる.

第 6 図は, ロー夕高さ $h=0.8$, 壁間隔 $w_{\mathrm{wr}}=1.5$ の 場合のロー夕まわりの流れ場である。この場合のロータま わりの流れ場には, 壁側のロー夕後流が翼端部でロー夕上 面から再循環することや，その影響により翼根部のアップ ウォッシュが壁側に傾くこと, また, ロー夕後流構造の対 称性が大きく失われていること等, $h=0.8, w_{\mathrm{wr}}=1.25$ の場合との共通点が存在する。しかし, ロー夕後流が一旦 地面に到達したのち, 壁に沿って上昇することや，ロー夕 外縁と壁の間隙を通過してロー夕面よりもかなり高い位置 に達することは， $h=0.8, \quad w_{\mathrm{wr}}=1.25$ の場合との相違点 である. 再循環流の大きさは $h=0.8, w_{\mathrm{wr}}=1.25$ の場合 より小さいが，これは，壁に沿って上昇する流れの一部が 壁の外側に流出するためと思われる。

ロータ高さ $h=0.8$, 壁間隔 $w_{\mathrm{wr}}=2.5$ の場合のロータ まわりの流れ場を第 7 図に示す。この場合の流れ場は, 壁 の位置がロータから遠いため, 壁近傍を除けば, $h=0.8$, $w_{\mathrm{wr}}=\infty$ の場合の流れ場とよく似ている. 壁に到達した 後のロータ後流は壁に沿って上昇し, 壁の上端まで達する が，その後は，ロータへ再循環することなく大部分は壁の 外側に流出して抢り, $h=0.8, w_{\mathrm{wr}}=1.25$ や $h=0.8$, $w_{\mathrm{wr}}=1.5$ の場合とは異なる流れ場を形成している. 


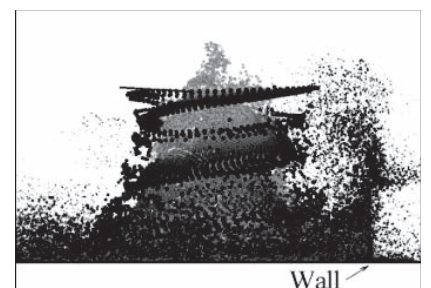

(a) パーティクルトレイス

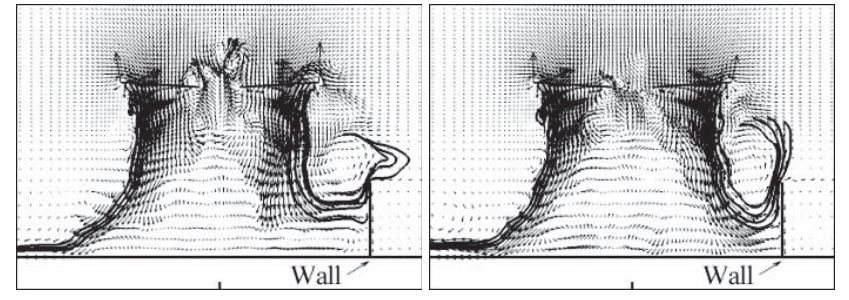

(b) $y z$ 平面速度ベクトル (縮流大)

(c) $y z$ 平面速度ベクトル (縮流小)

第 9 図 ロー夕まわりの流れ場 $\left(h=1.7, w_{\mathrm{wr}}=1.5\right)$

ロータ高さ $h=1.7$, 壁間隔 $w_{\mathrm{wr}}=1.25$ の場合は, 第 8 図 (a), (b) に示すように, 壁の位置がロータに近いにもか かわらず壁側で循環する流れはほとんど見られない.しか し，第 8 図 (b) に示すように，壁に到達したロー夕後流が 壁に沿って上昇する流れと地面に沿って半径方向内側に向 かう流れとに明暸に分かれるという，この場合に特有な流 れ場を形成している。壁に沿って上昇する流れは, 壁の上 端に達した後, 壁の外側へ流出するため, ロータから壁に 至るロー夕後流境界形状は, $h=1.7, w_{\mathrm{wr}}=\infty$ の場合の 後流境界形状とほぼ同じになっている。他方, 地面に沿っ て半径方向内側に向かう流れは, ロータ後流境界内部の流 れに影響を与えている。

ロータ高さ $h=1.7$, 壁間隔 $w_{\mathrm{wr}}=1.5$ の場合のロータ まわりの流れ場を第 9 図に示す. $h=1.7, w_{\mathrm{wr}}=1.25$ の 場合と同様に, 壁に到達したロータ後流には半径方向内側 に向かう流れも存在するが, $h=1.7, w_{\mathrm{wr}}=1.25$ の場合 ほど顕著ではなく，ほとんどのロータ後流は壁に沿って上 昇している。 その後, 壁の外側に流出していくロータ後流 も存在するが, その量は小さく大部分のロー夕後流は, ロー 夕面下，壁の間で大きく循環する流れの形成に寄与してい る.しかし，この循環する流れの大きさは，第 9 図 (b) 及 び (c) に示すように一定ではないため, 壁側の縮流の大き さも変動している。第 9 図 (b) のロータ後流境界は, 第 9 図 (c)よりも半径方向内側に近づいており縮流が大きくなっ ている，そのため，ロー夕後流境界内部の流れ場が影響を 受けていることがわかる.

ロータ高さ $h=1.7$, 壁間隔 $w_{\mathrm{wr}}=2.5$ の場合のロータ まわりの流れ場を第 10 図に示す. $h=0.8, \quad w_{\mathrm{wr}}=2.5$ の 場合と同様, ロータ後流は壁に到達した後, 壁に沿って上 昇し, 大部分は壁の外側に流出する。しかし, この場合は そのまま上昇しロータ上面に再循環する流れもわずかに存 在している.

4.2 ロータ面のインフロー分布 本節では, ブレード

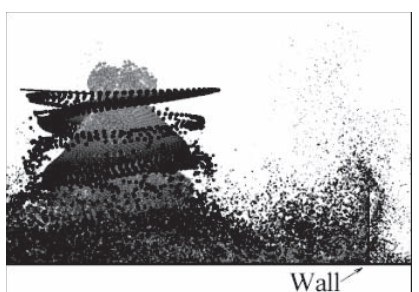

(a) パーティクルトレイス

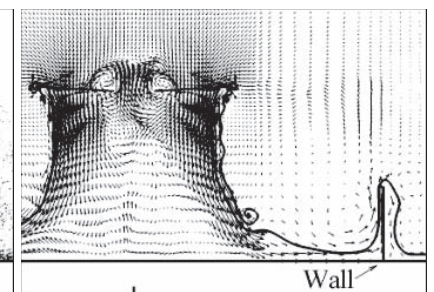

(b) $y z$ 平面速度ベクトル

第 10 図 ロータまわりの流れ場 $\left(h=1.7, \quad w_{\mathrm{wr}}=2.5\right)$

のフラッピング運動やロータの空力性能を決定する要因の ひとつであるロータ面のインフロー分布について考察する. 各計算条件におけるロータ面のインフロー $\lambda$ の分布を第 11 図に示す，ここでは， $\lambda$ は下向きを正，ブレードの約 0.2 コード長下の $z$ 方向の速度を翼端速度 $R \Omega$ で無次元化し た量とし，第 11 図では計算終了時のロータ 5 回転の平均 分布を表している。ただし，ロータ高さ $h=1.7$, 壁間隔 $w_{\mathrm{wr}}=1.5$ の場合は，ロータまわりの流れ場が一定しない ため, 縮流が大きい場合と小さい場合の $\lambda$ 分布を示した。

ロータ高さ $h=0.8$, 壁間隔 $w_{\mathrm{wr}}=\infty$ 及び $h=1.7$, $w_{\mathrm{wr}}=\infty$ の場合，4.1節で示したロータまわりの流れ場が ほぼ軸対称であったように，ロータ面のインフロー $\lambda$ の分 布も第 11 図 (a), (b) に示すよう, ほぼ軸対称になってい る。また，ロータ中心付近にアップウォッシュがあること など，ロータまわりの流れ場の様子と対応している．第 11 図 (a) と (b) を比較すると, 地面効果がより大きい $h=0.8$ の場合の $\lambda$ は, 無次元ロータ半径 $r \leq 0.8$ の範囲において $h=1.7$ の場合よりも值が小さくなっている.

第 11 図 (c) は, ロー夕高さ $h=0.8$, 壁間隔 $w_{\mathrm{wr}}=1.25$ の場合のロータ面のインフロー $\lambda$ の分布である. $h=0.8$, $w_{\mathrm{wr}}=\infty$ の場合と比較すると， $\lambda$ の分布が大きく異なって いることがわかる．壁があるブレード方位角 $\psi=3 \pi / 2$ 側 では, 無次元ロータ半径 $r \geq 0.6$ の範囲における $\lambda$ が大き くなっている. 一方, 壁と反対側の $\psi=\pi / 2$ 側では, 翼端 近傍の $\lambda$ が小さくなっている。 これは, ロータまわりの流 れ場で示したように, $\psi=3 \pi / 2$ 側にはロータ上面から再 循環する流れが存在することや $y z$ 平面における流れの非 対称性に起因している.

4.1 節で示したようにロー夕高さ $h=0.8$, 壁間隔 $w_{\mathrm{wr}}=$ 1.5 の場合も $h=0.8, \quad w_{\mathrm{wr}}=1.25$ の場合と同様に, 壁が あるブレード方位角 $\psi=3 \pi / 2$ 側に, ロー夕上面から再 循環する流れが存在し, $y z$ 平面の流れの対称性が失われ ていた，そのため，第 11 図 $(\mathrm{d})$ に示すように, $h=0.8$, $w_{\mathrm{wr}}=1.25$ の場合ほど明瞭ではないものの, $\psi=3 \pi / 2$ 側 の翼端付近のインフロー $\lambda$ が大きくなっている.

第 11 図 (e) は, ロー夕高さ $h=0.8$, 壁間隔 $w_{\mathrm{wr}}=2.5$ の場合のロータ面のインフロー $\lambda$ の分布である。この場合 は，他の場合と異なり，壁がある方位角とは $\pi / 2$ ずれてい る $x$ 軸に沿った部分の $\lambda$ 分布に変動が表れている.

ロータ高さ $h=1.7$, 壁間隔 $w_{\mathrm{wr}}=1.25$ の場合, 第 11 図 (f) に示すように, 無次元ロータ半径 $r \geq 0.4$ の範囲の 


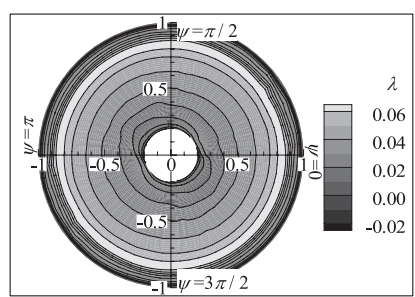

(a) $h=0.8, w_{\mathrm{wr}}=\infty$

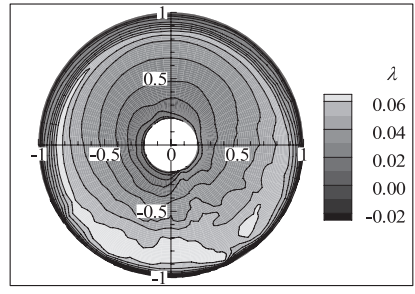

(c) $h=0.8, w_{\mathrm{wr}}=1.25$

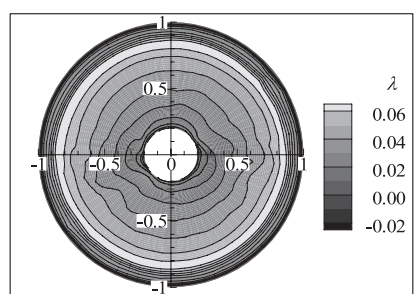

(e) $h=0.8, w_{\mathrm{wr}}=2.5$

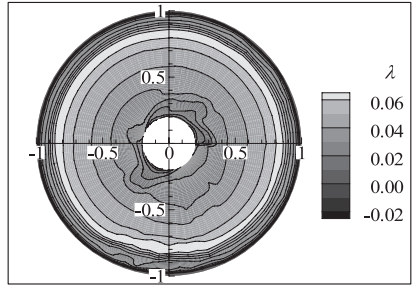

(g) $h=1.7, w_{\mathrm{wr}}=1.5$ (縮流大)

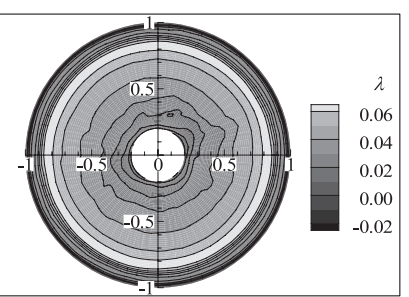

(b) $h=1.7, w_{\mathrm{wr}}=\infty$

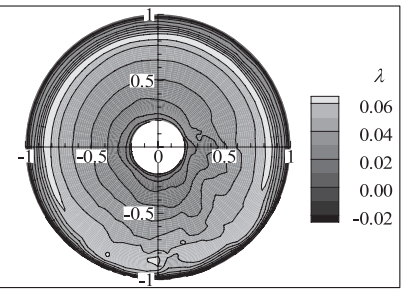

(d) $h=0.8, w_{\mathrm{wr}}=1.5$

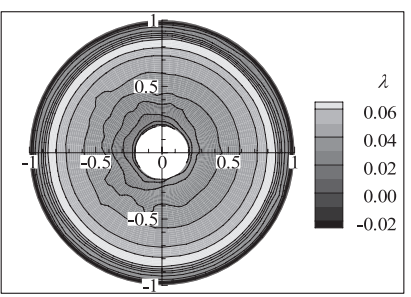

(f) $h=1.7, w_{\mathrm{wr}}=1.25$

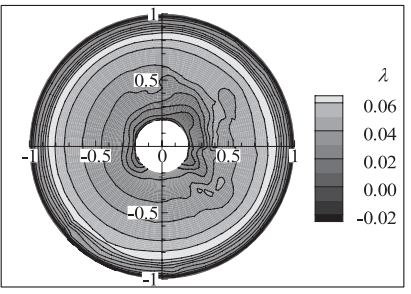

(h) $h=1.7, w_{\mathrm{wr}}=1.5$ (縮流小)

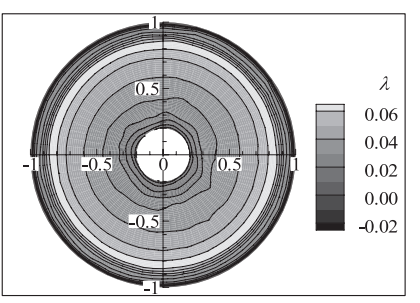

(i) $h=1.7, w_{\mathrm{wr}}=2.5$

第11図 ロータ面のインフロー分布

ロータ面のインフロー $\lambda$ の分布はほぼ軸対称となっており, 壁があるブレード方位角 $\psi=3 \pi / 2$ 側の $\lambda$ 分布はほとん ど変化していない. しかし, ロータ中心における $\lambda$ 分布に 着目すると, アップウォッシュの領域は, $0 \leq \psi \leq \pi$ で大 きく, $\pi \leq \psi \leq 2 \pi$ で小さいという特徵がみられる. $\lambda$ が このような分布となるのは, 壁側で循環する流れが形成さ れないことと, 壁に到達した後, 地面に沿ってロータ中心 に向かう流れによってロータ後流境界内部の流れが影響を 受けたことに起因している。このように，この場合の $\lambda$ 分 布に対する壁の影響は, 主として壁側の翼端付近ではなく 壁と反対側のロータ中心付近に表れる。

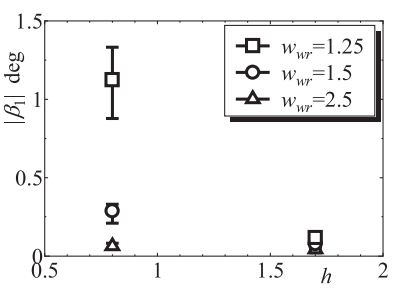

(a) フラッピング振幅

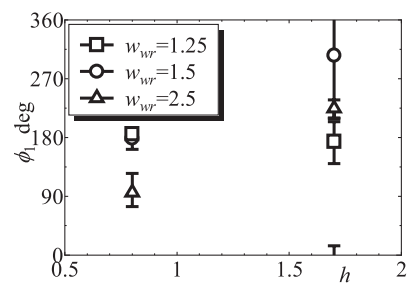

(b) 位相角
第 12 図 ブレードフラッピング運動

ロータ高さ $h=1.7$, 壁間隔 $w_{\mathrm{wr}}=1.5$ の場合, 4.1 節 で示したようにロータ面下, 壁との間に循環する流れが形 成される。その影響により, 壁側の縮流が大きくなった場 合のロータ面のインフロー $\lambda$ は, 第 11 図 $(\mathrm{g})$ に示される ように, ブレード方位角 $\psi=3 \pi / 2$ 付近でピーク位置がわ ずかに翼根側に移動している．また，このとき， $\psi \approx 3 \pi / 2$ の翼端付近の $\lambda$ は小さくなっており, 翼端部は循環する流 れによってアップウォッシュを受けていることがわかる。一 方，縮流が小さいときの $\lambda$ の分布は第 11 図 (h) に示され るように, $r \geq 0.6$ でほぼ軸対称となっているが, それよ り内側では $\lambda$ の分布に変化が見られる. $0 \leq \psi \leq \pi$ にお いてはロータ中心付近で $\lambda$ が小さくなり， $\pi \leq \psi \leq 2 \pi$ で は $\lambda$ が大きくなっており, $h=1.7, w_{\mathrm{wr}}=1.25$ の場合と 同様の傾向を示している.

第 11 図 (i) は, ロー夕高さ $h=1.7$, 壁間隔 $w_{\mathrm{wr}}=2.5$ の場合のロータ面のインフロー $\lambda$ の分布である。この場合 は，壁側でロー夕上面へわずかに再循環する流れが見られ たが, $h=1.7, w_{\mathrm{wr}}=\infty$ の場合と同様にほぼ軸対称な $\lambda$ 分布となっており, 明瞭には再循環流の影響が表れてい ない.

4.3 ブレードのフラッピング運動＼cjkstart本節では, ブレード のフラッピング運動に関する解析結果を示し, 前節までの 結果をもとにフラッピング運動が生じる要因について考察 する.

ブレードフラップ角 $\beta$ の解析結果は, 壁間隔 $w_{\mathrm{wr}}=\infty$ の場合を除いて 1 次調和項が卓越していた。 そこで, 各計 算条件における $\beta$ の解析結果を,

$$
\begin{aligned}
\beta & =a_{0}+a_{1} \cos \psi+b_{1} \sin \psi \\
& =a_{0}+\left|\beta_{1}\right| \cos \left(\psi-\phi_{1}\right)
\end{aligned}
$$

と, フーリエ級数 1 次近似したときのフラッピング振幅 $\left|\beta_{1}\right|$, 位相角 $\phi_{1}$ をそれぞれ第 12 図 (a), (b) に示す。各図の横 軸はロー夕高さ $h$ を表しており, $\left|\beta_{1}\right|, \phi_{1}$ ともに計算終了 時のロー夕 5 回転の值の変動幅を実線で, それらの平均值 を印で示している.

フラッピング振幅 $\left|\beta_{1}\right|$ の平均值は, ロータ高さ $h$ と壁 間隔 $w_{\mathrm{wr}}$ に著しく依存することがわかる. 特に, $h=0.8$, $w_{\mathrm{wr}}=1.25$ の場合, $\left|\beta_{1}\right|$ は他の場合より非常に大きく, 平 均值は $1^{\circ}$ を超えている.これは， 4.2 節で示したように, ブレード方位角 $\psi \approx 3 \pi / 2$ の翼端付近のインフロー $\lambda$ が 非常に大きいためである.

位相角 $\phi_{1}$ の平均值は, ロー夕高さ $h=0.8$, 壁間隔 
$w_{\mathrm{wr}}=2.5$, 及び $h=1.7, w_{\mathrm{wr}}=1.5$ の場合を除いて $180^{\circ}$ 前後となっている. $h=0.8, w_{\mathrm{wr}}=1.25$ と, $h=0.8$, $w_{\mathrm{wr}}=1.5$ の場合に $\phi_{1} \approx 180^{\circ}$ となるのは, 壁側の翼端 部に存在するロータ上面からの再循環流の影響で翼端部付 近のインフローが大きくなり，その結果，ブレード方位角 $\psi=3 \pi / 2$ 付近のフラップモーメントが小さくなるからで ある. $h=1.7, w_{\mathrm{wr}}=1.25$ の場合にも $\phi_{1} \approx 180^{\circ}$ と なっている.しかし, この場合のフラッピング運動の要因 は, 壁とは反対側のロータ中心付近のインフローが小さく なることで $\psi=\pi / 2$ 付近のフラップモーメントが大きくな ることにあり, $h=0.8$ の場合とは異なる. また, $h=1.7$, $w_{\mathrm{wr}}=2.5$ の場合も $\phi_{1} \approx 180^{\circ}$ となっている. この要因 は, 4.2 節のロー夕面のインフロー分布では明確に確認で きなかったが，4.1節で見られた，壁側での再循環流の影 響により, $\psi \approx 3 \pi / 2$ において，フラップモーメントがわ ずかに小さくなるためと考えられる． $h=1.7, w_{\mathrm{wr}}=1.5$ の場合の $\phi_{1}$ は， 4.1 節で示したようにロータまわりの流 れ場が独特な挙動を示すため, 平均值は約 $305^{\circ}$ で, 值の 変動幅は $180^{\circ} \leq \phi_{1} \leq 360^{\circ}$ と非常に大きい. このうち, $\phi_{1} \approx 0^{\circ}\left(360^{\circ}\right)$ となるのは壁側での縮流が大きい場合で ある. この場合, $\psi \approx 3 \pi / 2$ の翼端でアップウォッシュを受 けることに加えて，入のピーク位置が翼根側に移動するため フラップモーメントが大きくなり， $\phi_{1} \approx 0^{\circ}$ となる. また， $\phi_{1} \approx 180^{\circ}$ となるのは壁側での縮流が小さい場合で, その 要因は, $h=1.7, w_{\mathrm{wr}}=1.25$ の場合と同様に $\psi \approx \pi / 2$ のロータ中心付近の $\lambda$ が小さくなり, フラップモーメント が大きくなるためである. $h=0.8, w_{\mathrm{wr}}=2.5$ の場合は, 他の条件と異なり, ロータ面のインフロー分布に対する壁 の影響は $x$ 軸に沿った部分に表れるため, $\phi_{1} \approx 90^{\circ}$ となっ ている.

4.4 ロータ推力係数に対する壁の影響 各計算条件にお けるロー夕推力係数 $C_{\mathrm{T}}$ の解析結果を第 2 表に示す. ロー 夕高さ $h=1.7$, 壁間隔 $w_{\mathrm{wr}}=1.5$ の場合には, ロー夕面 下，壁との間に循環流が形成され，その大きさが変動した。 しかし, 第 11 図 $(\mathrm{g}),(\mathrm{h})$ に示すように, その変動による インフローの平均的な大きさに対する影響はほとんどなく, 循環流の大きさが変動しても， $C_{\mathrm{T}}$ はほぼ一定であった。 な お, 第 2 表に示した $C_{\mathrm{T}}$ は計算終了時のロータ 5 回転の平 均值である。

壁間隔 $w_{\mathrm{wr}}=\infty$ の場合, 地面効果が大きいロー夕高 さ $h=0.8$ の $C_{\mathrm{T}}$ の方が, $h=1.7$ の場合よりも大きく

第 2 表 ロー夕推力係数 $C_{\mathrm{T}}$

\begin{tabular}{lc}
\hline \multicolumn{1}{c}{ 計算条件 } & $C_{\mathrm{T}}$ \\
\hline$h=0.8, w_{\mathrm{wr}}=\infty$ & $5.00 \times 10^{-3}$ \\
$h=0.8, w_{\mathrm{wr}}=1.25$ & $4.47 \times 10^{-3}$ \\
$h=0.8, w_{\mathrm{wr}}=1.5$ & $4.72 \times 10^{-3}$ \\
$h=0.8, w_{\mathrm{wr}}=2.5$ & $5.00 \times 10^{-3}$ \\
$h=1.7, w_{\mathrm{wr}}=\infty$ & $4.43 \times 10^{-3}$ \\
$h=1.7, w_{\mathrm{wr}}=1.25$ & $4.46 \times 10^{-3}$ \\
$h=1.7, w_{\mathrm{wr}}=1.5$ & $4.42 \times 10^{-3}$ \\
$h=1.7, w_{\mathrm{wr}}=2.5$ & $4.34 \times 10^{-3}$ \\
\hline
\end{tabular}

なっている。これは， 4.2 節で示したように無次元ロータ 半径 $r \leq 0.8$ の範囲において $h=0.8$ のインフロー $\lambda$ が $h=1.7$ の場合よりも小さくなり, その範囲の局所推力が 大きくなるためである. $w_{\mathrm{wr}}=2.5$ の場合は, $h=0.8$ の $C_{\mathrm{T}}$ が $w_{\mathrm{wr}}=\infty$ の場合に一致しているのに対し, $h=1.7$ の $C_{\mathrm{T}}$ は $w_{\mathrm{wr}}=\infty$ の場合の $C_{\mathrm{T}}$ より約 $2 \%$ 小さくなって いる.これは，ロータ面のインフロー $\lambda$ 分布では明瞭でな かったが、ロー夕まわりの流れ場で見られたロー夕上面か ら再循環する流れの影響によるものと思われる。また，ロー 夕が壁に近い $w_{\mathrm{wr}}=1.25, w_{\mathrm{wr}}=1.5$ の場合でも, ロータ 高さが大きい $h=1.7$ の場合は, $C_{\mathrm{T}}$ に対する壁の影響は ほとんど表れていない. しかし， $h=0.8$ の場合には， $C_{\mathrm{T}}$ に対する壁の影響は顕著で, $w_{\mathrm{wr}}$ が小さいほど $C_{\mathrm{T}}$ は小さ くなり, $w_{\mathrm{wr}}=1.25$ の場合には, $w_{\mathrm{wr}}=\infty$ の $C_{\mathrm{T}}$ よりも 約 10\%小さくなっている。これは，ロータまわりの流れ場 と $\lambda$ 分布において明瞭に示されたように, ロータ上面から 再循環する流れが存在するため, 地面効果を十分に得られ るロータ高さでホバリングしているにもかかわらず，地面 効果を得にくくなっていることを示している.

このように，ロー夕高さ $h=0.8$, 壁間隔 $w_{\mathrm{wr}}=1.25$, $h=0.8, w_{\mathrm{wr}}=1.5$, 及び $h=1.7, w_{\mathrm{wr}}=2.5$ のロータ 推力係数 $C_{\mathrm{T}}$ が, それぞれ, $w_{\mathrm{wr}}=\infty$ の場合の $C_{\mathrm{T}}$ より 小さくなる要因は, ロー夕上面からの再循環流が主である と思われる。しかし， $C_{\mathrm{T}}$ の大小を決定するブレードの有 効迎え角は，インフロー入の他にフラッピング運動によっ て相対的に生じる速度 $r \mathrm{~d} \beta / \mathrm{d} \psi$ の影響も受ける。 そこで, 以下では， $C_{\mathrm{T}}$ に対する $\lambda$ と $r \mathrm{~d} \beta / \mathrm{d} \psi$ の影響について検 討する.

初めに, ロー夕高さ $h=0.8$, 壁間隔 $w_{\mathrm{wr}}=1.25$ の場 合について考察する。第 13 図 (a) は, ロー夕面上の推力分 布に関する $w_{\mathrm{wr}}=1.25$ と $w_{\mathrm{wr}}=\infty$ との差を表す $\Delta C_{\mathrm{T}}$ 分布を示したものである. したがって， $\Delta C_{\mathrm{T}} \geq 0$ の部分 は, $w_{\mathrm{wr}}=1.25$ の場合の方が $w_{\mathrm{wr}}=\infty$ の場合よりも局所 推力が大きくなっていることを表し， $\Delta C_{\mathrm{T}} \leq 0$ の部分は, $w_{\mathrm{wr}}=1.25$ の場合の方が $w_{\mathrm{wr}}=\infty$ の場合よりも局所推力 が小さくなっていることを表している，第 13 図 (a) に示す ように, ブレード方位角 $\psi$ が $\pi \leq \psi \leq 3 \pi / 2$ のロータ中心 付近, 及び $\psi \approx 5 \pi / 3$ の翼端近傍に $\Delta C_{\mathrm{T}} \geq 0$ の領域があ るものの，他の領域では $\Delta C_{\mathrm{T}} \leq 0$ となっている。 これは, 再循環流の影響が顕著に表れる $\psi=3 \pi / 2$ 側ばかりでなく, ロータ面のほぼ全域にわたって,$w_{\mathrm{wr}}=\infty$ の場合より局所

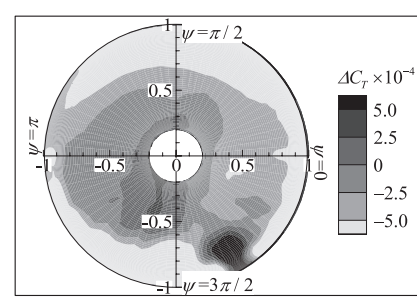

(a) $\Delta C_{\mathrm{T}}$ 分布

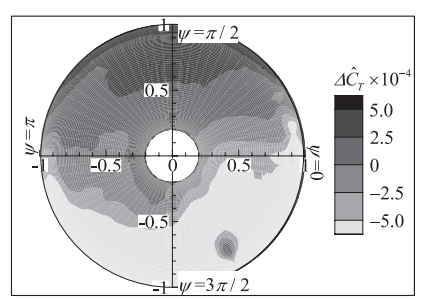

(b) $\Delta \hat{C}_{\mathrm{T}}$ 分布
第 13 図 ロー夕面の推力係数分布 $\left(h=0.8, w_{\mathrm{wr}}=1.25\right)$ 
推力が小さくなることを示している. $\Delta C_{\mathrm{T}}$ 分布には，イン フロー $\lambda$ とフラッピングによる相対速度 $r \mathrm{~d} \beta / \mathrm{d} \psi$ の双方 の影響が含まれている，そこで，入のみの影響を顕在化さ せるために, $h=0.8, w_{\mathrm{wr}}=1.25$ に扔いて $r \mathrm{~d} \beta / \mathrm{d} \psi$ の影 響分を除いて作成したロー夕面上の推力分布と $w_{\mathrm{wr}}=\infty$ の推力分布との差により求めた $\Delta \hat{C}_{\mathrm{T}}$ 分布を第 13 図 (b) に示す. $\Delta \hat{C}_{\mathrm{T}}$ 分布は, 壁と反対側の $0 \leq \psi \leq \pi$ の領域 で $\Delta \hat{C}_{\mathrm{T}} \geq 0$ となり, 壁側の $\pi \leq \psi \leq 2 \pi$ の範囲では, 第 13 図 (a)に扔いて $\Delta C_{\mathrm{T}} \geq 0$ であったロー夕中心付近や $\psi \approx 5 \pi / 3$ の翼端部の領域でもほほ $\Delta \hat{C}_{\mathrm{T}}<0$ になってい る. このように, $\Delta C_{\mathrm{T}}$ 分布と $\Delta \hat{C}_{\mathrm{T}}$ 分布は全く異なるが, $r \mathrm{~d} \beta / \mathrm{d} \psi$ の影響分を除いた， $\lambda$ のみ影響によるロー夕推 力倸数 $\hat{C}_{\mathrm{T}}$ を求めると, $\hat{C}_{\mathrm{T}}=4.48 \times 10^{-3}$ となり, $C_{\mathrm{T}}$ $\left(=4.47 \times 10^{-3}\right)$ と差のない結果となった. 4.2 節， 4.3 節 で示した結果，及び第 13 図(a), (b) による考察よりロー 夕面のほぼ全域で $w_{\mathrm{wr}}=\infty$ の場合よりも局所推力が小さ くなるメカニズムを推察すると, 以下のようにまとめられ る. 第 11 図 (c)で示したように, 壁がある $\psi=3 \pi / 2$ 側で は，再循環流によってインフロー $\lambda$ が極めて大きくなる一 方で, $\psi=\pi / 2$ 側ではロー夕後流境界内部の流れ場の変化 等の影響によりインフローが小さくなる。このとき, 再循 環流による影響の方が支配的であるため， $C_{\mathrm{T}}$ は小さくな る.また, $\lambda$ がこのような分布になることで, 4.3 節で示し たように, 振幅 $\left|\beta_{1}\right| \approx 1.1^{\circ}$, 位相角 $\phi_{1} \approx 180^{\circ}(=\pi)$ の 1 次のフラッピング運動が誘起される。 このとき, $r \mathrm{~d} \beta / \mathrm{d} \psi$ は $\psi \approx \pi / 2$ で最大, $\psi \approx 3 \pi / 2$ で最小となる. そのため, $\psi=\pi / 2$ 側ではブレードのフラップアップに伴い, 下向き の相対速度が大きくなり, $\lambda$ の減少による局所推力の増加 が緩和され， $\psi=3 \pi / 2$ 側においてはフラップダウンに伴 い上向きの相対速度が大きくなるため, $\lambda$ の増加による局 所推力の減少が緩和される. その結果, 推力分布が均一化 された状態でロー夕推力係数 $C_{\mathrm{T}}$ が小さくなる.

次に, ロー夕高さ $h=0.8$, 壁間隔 $w_{\mathrm{wr}}=1.5$ の場合 に, $w_{\mathrm{wr}}=\infty$ の場合よりもロー夕推力係数 $C_{\mathrm{T}}$ が小さ くなる要因について考察する，前節までに示してきたよう に, $h=0.8, w_{\mathrm{wr}}=1.5$ の場合, ロー夕まわりの流れ 場やロータ面のインフロー分布に関する特徵は $h=0.8$, $w_{\mathrm{wr}}=1.25$ の場合とほぼ同様で, ブレードのフラッピング 運動も, フラッピング振幅 $\left|\beta_{1}\right|$ が小さいものの, 位相角 $\phi_{1}$ はほぼ同じであった。このため, $w_{\mathrm{wr}}=1.5$ の場合の $C_{\mathrm{T}}$ が $w_{\mathrm{wr}}=\infty$ の場合よりも小さくなる要因は, $w_{\mathrm{wr}}=1.25$ の場合と同様に説明される。 よって, 以下では推力分布に 関する $w_{\mathrm{wr}}=1.25$ の場合との相違点について示す. 第 14 図 (a) 及び (b) は, それぞれ, $w_{\mathrm{wr}}=1.5$ の場合の $\Delta C_{\mathrm{T}}$ 分布と $\Delta \hat{C}_{\mathrm{T}}$ 分布である. $\Delta C_{\mathrm{T}}$ 分布に打いて, $\psi \approx 3 \pi / 2$ で局所的に $\Delta C_{\mathrm{T}} \geq 0$ となっている領域が見られるもの の, 全体的に $\Delta C_{\mathrm{T}} \leq 0$ となっているため, 定性的には $w_{\mathrm{wr}}=1.25$ と同様の傾向といえる. 一方, $\Delta \hat{C}_{\mathrm{T}}$ 分布は, $w_{\mathrm{wr}}=1.25$ の場合と異なり, $\psi=\pi / 2$ 側に扔いても, 翼 端部を除き $\Delta \hat{C}_{\mathrm{T}} \leq 0$ となっている.

最後に, ロー夕高さ $h=1.7$ の場合に, 壁間隔 $w_{\mathrm{wr}}=\infty$

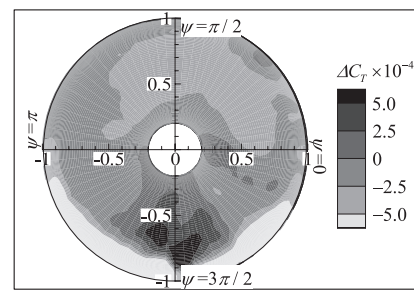

(a) $\Delta C_{\mathrm{T}}$ 分布

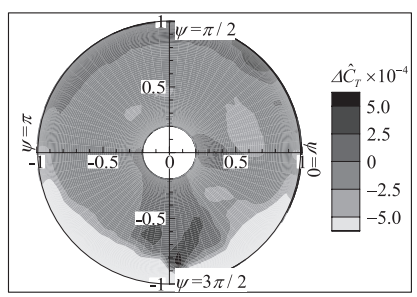

(b) $\Delta \hat{C}_{\mathrm{T}}$ 分布
第 14 図 ロー夕面の推力係数分布 $\left(h=0.8, \quad w_{\mathrm{wr}}=1.5\right)$

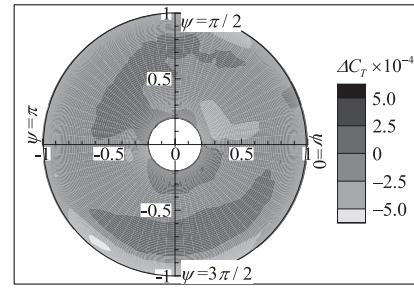

(a) $\Delta C_{\mathrm{T}}$ 分布

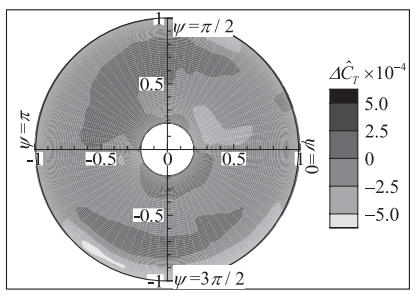

(b) $\Delta \hat{C}_{\mathrm{T}}$ 分布
第 15 図 ロー夕面の推力係数分布 $\left(h=1.7, w_{\mathrm{wr}}=2.5\right)$

の場合よりロータ推力係数 $C_{\mathrm{T}}$ が小さくなる $w_{\mathrm{wr}}=2.5$ の場合の $\Delta C_{\mathrm{T}}$ 分布と $\Delta \hat{C}_{\mathrm{T}}$ 分布を第 15 図 (a), (b) に示 す、第 15 図 (a)を見ると、ロー夕面のほほ全域にわたっ て $\Delta C_{\mathrm{T}} \leq 0$ となっているため, この場合も $h=0.8$, $w_{\mathrm{wr}}=1.25$ や $h=0.8, \quad w_{\mathrm{wr}}=1.5$ と同様にロー夕面全 域にわたって局所推力が減少することで $w_{\mathrm{wr}}=\infty$ の場 合よりも $C_{\mathrm{T}}$ が小さくなることがわかる. 第 15 図 (b)で は, $\psi=3 \pi / 2$ 側の翼端近傍に扔いて明確に局所推力が小 さくなる部分が見られ，ロータ面のインフロー分布では明 瞭でなかった再循環流の影響が確かに存在することが示さ れている.これによって，4.3節で示したフラッピング振 幅 $\left|\beta_{1}\right| \approx 0.05^{\circ}$ ，位相角 $\phi_{1} \approx 180^{\circ}$ のわずかなブレードフ ラッピング運動は, 再循環流の影響により $\psi=3 \pi / 2$ 側の フラッピングモーメントが小さくなることで生じたことが わかる。また，第 15 図 (a) と (b) を比較すると， $\Delta \hat{C}_{\mathrm{T}}$ 分 布は $\psi=\pi / 2$ 側における $\Delta \hat{C}_{\mathrm{T}} \geq 0$ の領域と $\psi=3 \pi / 2$ 側における $\Delta \hat{C}_{\mathrm{T}} \leq 0$ の領域がそれぞれ大きくなっている ものの, $\left|\beta_{1}\right|$ が非常に小さいため, $\Delta C_{\mathrm{T}}$ 分布からの変化 はわずかであることがわかる.

$4.5 \mathrm{CFD}$ 解析結果の妥当性の検討 本節では, ロータ 推力倸数とフラッピング運動に関する CFDによる解析結 果と模型ロータブレードを用いて行った実験結果8) との比 較を行い，本解析結果の妥当性について検討する，実験に 㧍けるコレクティブピッチ角 $\theta_{0}$ は, 本解析で得た各壁間 隔 $w_{\mathrm{wr}}$ でのロー夕高さ $h=0.8$ に扔けるロー夕推力係数 $C_{\mathrm{T}}$ になるように設定した。 そして， $\theta_{0}$ をその值に固定し たまま, $h=1.7$ における $C_{\mathrm{T}}$ 及びフラッピング振幅 $\left|\beta_{1}\right|$ と位相角 $\phi_{1}$ を測定した。 ここでは, 計算終了判定の基準 とした $C_{\mathrm{T}}$ と $\phi_{1}$ に関する比較を行う.

第 16 図は, 壁間隔ごとに示したロー夕推力係数 $C_{\mathrm{T}}$ に関 する CFD による解析值と実験值との比較である。横軸は ロー夕高さ $h$ で, ○印は CFD の解析結果, 一印が実験結 


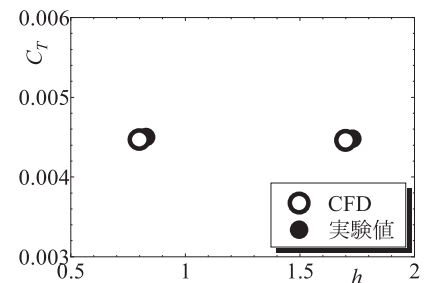

(a) $w_{\mathrm{wr}}=1.25$

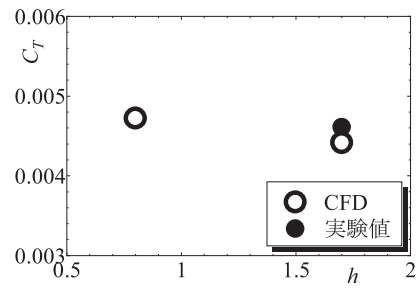

(b) $w_{\mathrm{wr}}=1.5$

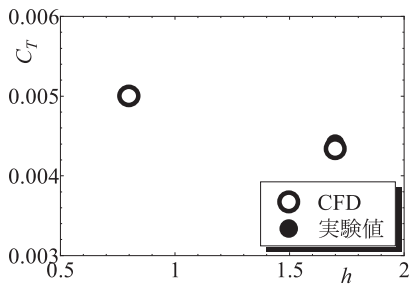

(c) $w_{\mathrm{wr}}=2.5$

第 16 図 ロー夕推力係数に関する実験結果との比較

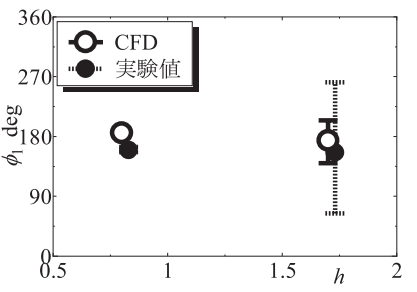

(a) $w_{\mathrm{wr}}=1.25$

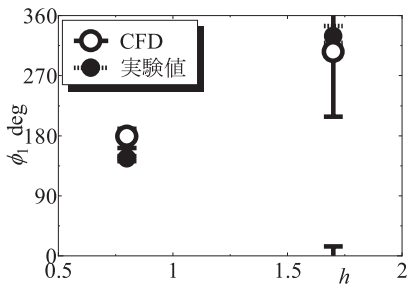

(b) $w_{\mathrm{wr}}=1.5$

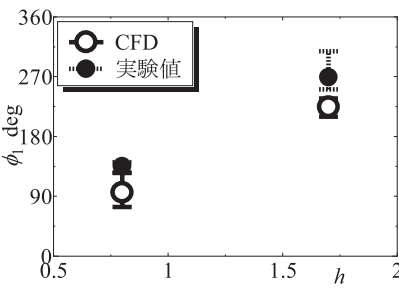

(c) $w_{\mathrm{wr}}=2.5$

第 17 図 フラップ角の位相角に関する実験結果との比較

果を表している. ロータ高さ $h=1.7$, 壁間隔 $w_{\mathrm{wr}}=1.5$ の場合の解析值と実験值とに $4.4 \%$ 程度の差が見られるもの の, 他の場合の解析值と実験值はよい一致を示している.

第 17 図は，壁間隔ごとに示したブレードフラップ角 $\beta$ の位相角に関する CFDによる解析值と実験值との比較で ある. 横軸はロー夕高さ $h$ で, 縦軸は位相角 $\phi_{1}$ を示して いる. CFDによる解析值は, 計算終了時のロータ 5 回転の 值の変動幅を実線で示し, それらの平均值を○印で示して いる. 実験值は, FFT 処理により取得した 4 回のデータの 変動幅を点線で示し, 平均值を○印で示している。 $\phi_{1}$ は, $h=1.7$ の場合において, 值の変動幅に差があるものの平 均值は概ねよい一致を示している。

以上のように, CFDによる解析值と実験值は, ロータ推 力係数 $C_{\mathrm{T}}$, および, 位相角 $\phi_{1}$ の平均值において概ねよい 一致を示しており, 本解析によって壁がある地面近傍でホ バリングするロー夕まわりの平均的な流れ場は妥当な範囲 でとらえられていると考える。一方で，ロー夕高さ $h=1.7$ の $\phi_{1}$ には, CFD 解析值と実験值との間で值の変動幅に差 が見られる。この一因としては，ロータと壁との間に形成 される循環流の位置や強さと, ロータ後流境界内部の流れ 場に対する粘性, 地面や壁の境界層の影響が考えられる。

\section{5. 結論}

本研究では，建物や高速道路の側壁等を模擬した 1 枚の 壁がある地面近傍でホバリングするヘリコプタロータに関 して, ロータ高さと壁間隔をパラメータとした, 非定常 3 次元圧縮性 Euler 方程式による CFD 解析を行った。本研 究により得られた知見を以下に示す.

1）ロータまわりの流れ場は，ロー夕高さと壁間隔の組み 合わせに大きく依存し多様である.

2）壁が無い場合と比較してロー夕推力係数が小さくなる
場合, 推力係数を小さくする主要因はロータ上面からの再 循環流である。その際，ブレードフラッピング運動が生じ るため, ロータ面のほほ全域の局所推力が均一化されて小 さくなる。

3）ロータ面のインフロー分布は, 循環する流れによって 影響を受けるばかりではなく，ロー夕後流境界内部の流れ が変わることでも影響を受ける。

4）フラッピング運動の位相角が等しい場合でも, 位相角 を決定する要因が異なる場合がある。

\section{参 考 文 献}

1）臼田裕幸, 井星正氣, 糸賀紀晶：狭い空間上でホバリングする ロータの空力性能, 日本航空宇宙学会第 44 回飛行機シンポジウ 么講演集, 2006, pp. 94-98.

2）臼田裕幸, 井星正氣, 糸賀紀晶：狭い空間上でホバリングする ロー夕の地面効果（壁間隔に対して非対称な位置にあるロータの 空力性能), 日本航空宇宙学会第 45 回飛行機シンポジウム講演 集, 2007, pp. 1206-1211.

3）井星正氣, 臼田裕幸, 糸賀紀晶：狭い空間上でホバリングする ロー夕の地面効果（壁間隔に対して非対称な位置にあるロータの 変動荷重), 日本航空宇宙学会第 45 回飛行機シンポジウム講演 集, 2007, pp. 1212-1221.

4）臼田裕幸: 狭い空間上でホバリングするヘリコプタロータの空力 性能, 防衛大学校第 45 期理工学研究科修士論文, 2008 .

5) Roe, P. L.: Approximate Riemann Solvers, Parameter Vectors and Difference Schemes, J. Comput. Phys., 43 (1981), pp. 357-372.

6) 山本 悟, 大宮司久明 : Fourth-Order Compact MUSCL TVD スキームによる超音速流れの数值シミュレーション, 航空宇宙技 術研究所特別資料, 1991, pp. 357-372.

7) Jameson, A., Schmidt, W. and Turkel, E.: Numerical Solution of the Euler Equations by Finite Volume Methods Using Runge-Kutta Time-Stepping Schemes, AIAA Paper 81-1259, 1981.

8) 粉川裕介：ヘリコプタのロータ必要パワーと操縦性に及ぼす狭い 空間の影響, 防衛大学校第 47 期理工学研究科修士論文, 2010 .

9) Leishman, J. G.: Principles of Helicopter Aerodynamics, Cambridge University Press, New York, 2006, pp. 257-262. 